\title{
The Ibn Sina Perspective on Education Concept
}

\author{
Minten Apriani ${ }^{1}$, Syahidin ${ }^{1 *}$ \\ 1 Prodi Pendidikan Agama Islam, Sekolah Pascasarjana, Universitas Pendidikan Indonesia, Bandung, Indonesia
}

\section{ARTICLE INFO ABSTRACT}

\section{Keywords}

Ibnu Sina, Thought, Education

\section{*Correspondence \\ mintenapriani96@upi.edu}

\section{Article History}

Received 25 March 2021

Accepted 25 June 2021

Published online 27 June 2021

\begin{abstract}
In essence, education wants students besides they have extensive knowledge, they also have noble morals and have skills based on their interests. Of the many figures of Islamic education, this study will focus more on Ibn Sina's thoughts on education. This study aims to identify education from Ibn Sina's perspective, especially concerning ideal teachers. The research also is expected to give an alternative solution to all kinds of problems in the education world. This research uses a qualitative approach with a library research method. The data collection technique in this research is based on the information contained in literature sources, both in books and journals relevant to the research theme. The journals used in this study amounted to twenty-one journals from 2014 to 2020 . At the same time, the books used in this study amounted to two books spanning 2015 to 2017. The research results indicate that Ibn Sina's thoughts on the concept of education emphasize the achievement of a perfect human. According to Ibn Sina, there are four main points of educational thought, including educational goals, curriculum concepts, learning methods, and educator concepts. These concepts are still very relevant to current education. Based on this, according to Ibn Sina, the concept of education should be emulated and developed by education practitioners in modern times, especially in the development of Islamic education in Indonesia.
\end{abstract}

\section{PENDAHULUAN}

Pendidikan merupakan bagian penting bagi kehidupan manusia. Majunya peradaban suatu bangsa tentunya dipengaruhi oleh sumber daya manusia yang berkualitas. Namun, jika sumber daya manusianya tidak memiliki kualitas yang baik dari berbagai bidang, maka tidak dapat dipungkiri bahwa bangsa tersebut akan tertinggal dari segala aspek kehidupan (Hidayat et al., 2018). Disini pendidikan memiliki peranan yang cukup penting dalam membina sumber daya manusia yang berkualitas. Pendidikan dengan berbagai coraknya berorientasi memberikan bekal kepada manusia untuk mencapai kebahagiaan dunia dan akhirat. Selain itu, dengan pendidikan juga manusia dapat menghadapi alam semesta demi mempertahankan hidupnya. Karena pentingnya pendidikan, Islam menempatkan pendidikan pada kedudukannya yang penting dan juga tinggi. Adapun pengertian pendidikan berdasarkan UUD No.20 Tahun 2003 tentang Sistem Pendidikan Nasional menyatakan bahwa pendidikan adalah usaha sadar dan terencana untuk mewujudkan suasana dan proses belajar dan proses pembelajaran agar peserta didik secara aktif mengembangkan potensi dirinya untuk memiliki kekuatan spiritual keagamaan pengendalian diri, kepribadian, kecerdasan akhlak, mulia serta keterampilan yang diperlukan dirinya, masyarakat bangsa dan Negara (Sujana, 2019). Berdasarkan hal tersebut, sudah jelas bahwa pendidikan diarahkan pada pengembangan potensi serta keterampilan yang dimiliki oleh peserta didik. Selain itu, pendidikan juga diarahkan agar peserta didik beriman dan bertakwa kepada Tuhan Yang Maha Esa dan memiliki akhlak yang mulia.

Namun, pada kenyataannya realita dunia pendidikan saat ini yang telah dipengaruhi oleh arus globalisasi ternyata sedang mengalami problematika yang sangat mengkhawatirkan. Kemajuan ilmu dan pengetahuan di sisi lain telah membawa kecenderungan-kecenderungan yang bersifat destruktif bagi kehidupan manusia. Munculnya kenakalan remaja, maraknya konsumsi minuman keras, narkoba, pergaulan bebas, hamil di luar nikah, aborsi, tawuran pelajar, serta kekerasan adalah bukti yang tidak ternafikan akibat dampak negatif dari pesatnya arus globalisasi saat ini.

Menurut kepala Badan Narkotika Nasional (BNN) Komisiaris Jenderal Polisi Heru Winarko dalam bnn.go.id, 12/08/2019 menyatakan bahwa penyalahgunaan narkotika di kalangan remaja semakin meningkat jika dibandingkan dengan tahun-tahun sebelumnya, di mana ada peningkatan sebesar 24 hingga 28\% remaja yang menggunakan narkotika. Dalam artikel ini dijelaskan pula menurut World Drugs Reports 2018 yang diterbitkan oleh United Nations Office on Drugs and Crime (UNODC), menyebutkan sebanyak 275 juta penduduk di dunia atau 5,6\% dari penduduk dunia (usia 15-64 tahun) pernah mengonsumsi narkoba. Sementara di Indonesia, BNN selaku focal point di bidang Pencegahan dan Peredaran Gelap Narkoba (P4GN) mengantongi angka penyalahgunaan narkoba pada tahun 2017 sebanyak 3.376.115 orang pada rentang usia 10-59 tahun. Sedangkan angka

(C) 2021 by the authors; licensee PRIMA, Hannover, Germany. This is an Open Access article distributed under the terms of the Creative Commons Attribution-ShareAlike 4.0 International License. (https://creativecommons.org/licenses/by-sa/4.0/), which permits unrestricted use, distribution, and reproduction in any medium, provided the original work is properly cited. 
penyalhgunaan narkoba di kalangan pelajar di tahun 2018 dari 13 ibukota provinsi di Indonesia, mencapai 2,29 juta orang (bnn.go.id, 12/08/2019).

Berdasarkan Riset Kesehatan Dasar Departemen Kesehatan pada 2007 mengungkapkan data jumlah remaja pengomsumsi miras di Indonesia masih diangka 4.9\%, akan tetapi pada 2014 berdasarkan hasil riset yang dilakukan oleh Gerakan Nasional Anti Miras (GeNAM) jumlahnya melonjak drastic hingga mencapai angka 23\% dari total jumlah remaja Indonesia yang pada tahun 2018 berjumlah 63 juta jiwa (Hidayat et al., 2018).

Adanya pengaruh budaya dari negara-negara barat yang mengumbar pergaulan bebas banyak meracuni pemikiran para peserta didik, sehingga pada akhirnya dapat melemahkan nilai-nlai agama dan moral mereka. Misalnya seperti pergaulan antara laki-laki dan perempuan seakan-akan tidak ada lagi batas norma agama, cara berpakaian pun sudah banyak yang menyimpang dari ajaran Islam, seperti perempuan berpakaian lebih terbuka daripada menutup auranya, dengan alas an trend modern dan lainnya, bahkan ironisnya terkadang budaya-budaya dan pakaian yang bernuansa islami dianggap tidak relevan, norak, dan ketinggalan zaman (Baiturrahman, 2018).

Selanjutnya, dalam riset yang dilakukan oleh Lembaga Kajian dan Pengembangan Sumber Daya Manusia (Lakpesdam) Pengurus Wilayah Nahdhatul Ulama (PWNU) DKI Jakarta bersama Pusat Penguatan Otonomi Daerah (PPOD) mengungkapkan data dalam pikiran-rakyat.com (15/8/2017) bahwa konsumsi minuman beralkohol oplosan oleh anak di bawah umur angkanya cukup tinggi, yakni sekitar 65,3 \%. Riset itu sendiri melibatkan sebanyak 372 responden remaja yang berusia $12-21$ tahun di wilayah Jakarta, Bogor, Depok, Tangerang, dan Bekasi (Syafe'i, 2018). Selain itu, akhlak mulia seperti kejujuran, keadilan, tolong menolong, saling mengasihi, toleransi, dan akhlak mulia lainnya sedikit demi sedikit sudah mulai terkikis oleh sikap tidak peduli, penipuan, permusuhan, penindasan, saling menjatuhkan, mengambil hak orang lain secara paksa, dan perbuatan-perbuatan tercela lainnya (Iskarim, 2016).

Berdasarkan permasalahan di atas, perlu adanya sebuah solusi untuk menyelesaikannya. Dalam hal ini, bagaimana di dalam proses pendidikan itu tidak hanya ditekankan kepada aspek kognitif saja, melainkan juga harus memperhatikan aspek-aspek lainnya, seperti aspek afektif dan psikomotoriknya, terutama penanaman nilai-nilai yanga ada di dalam mata pelajaran Pendidikan Agama Islam Islam (PAI). Dari sekian banyak pemikiran-pemikiran para tokoh pendidikan yang ada, pemikiran pendidikan yang dilontarkan oleh Ibnu Sina diharapkan mampu menjadi cerminan bagi perbaikan dan pengembangan pendidikan di Indonesia, khusunya dalam pendidikan Islam agar lebih baik lagi kedepannya.

Ibnu Sina merupakan salah satu ilmuwan muslim yang telah memberikan pengaruh bagi kemajuan ilmu pengetahuan. Selain itu, Ibnu Sina juga merupakan salah satu ilmuwan muslim yang memiliki keahlian multi bidang, diantaranya bidang agama, filsafat, kedokteran, psikologi dan juga pendidikan. Pemikiran Ibnu Sina bukan hanya memberikan pengaruh besar bagi peradaban Islam, lebih dari itu pemikiran dan karya-karya Ibnu Sina telah memberikan sumbangsih bagi perkembangan ilmu pengetahuan di dunia (Shofiyah, 2019). Selain itu, Ibnu Sina juga merupakan tokoh pemikir muslim yang memadukan antara dimensi rasional dan religiusitas. Keduanya adalah hal yang saling mendukung satu sama lain dalam memecahkan persoalan dan realitas kehidupan. Fenomena kehidupan manusia dan fenomena alam merupakan realitas yang harus dimaknai dengan menggunakna sudut pandang yang beragam (Putra, 2015). Beragam latar belakang keilmuan yang dimiliki oleh Ibnu Sina dan profesinya yang pernah menjadi pendidik (guru) dan peserta didik memiliki andil yang cukup banyak dalam menuangkan berbagai pemikirannya tentang pendidikan. Artinya, pemikiran Ibnu Sina tentang pendidikan bukan hanya sekedar teori semata, melainkan juga praktik dari apa yang dialaminya ketika mendidik dan juga mengajar. Selain itu, ilmu yang dikuasainya pun turut membantu dalam pemikirannya tentang pendidikan (Azhari, 2020).

Terdapat empat point pemikiran filosofis Ibnu Sina dalam bidang pendidikan, diantaranya yaitu tujuan pendidikan, konsep kurikulum pendidikan, konsep metode pembelajaran, dan konsep pendidik atau guru. Terkait dengan tujuan pendidikan, Ibnu Sina menyatakan bahwa tujuan dari pendidikan itu harus diarahkan pada pengembangan seluruh potensi yang dimiliki seseorang kea rah perkembangan yang sempurna, yakni seimbang antara perkembangan fisik, intelektual, dan budi pekerti. Selain itu, tujuan pendidikan menurut Ibnu Sina juga harus diarahkan pada upaya mempersiapkan seseorang agar dapat hidup di masyarakat secara bersama dengan melakukan pekerjaan atau keahlian yang dipilihnya sesuai dengan bakat, kesiapan, kecenderungan, dan juga potensi yang dimilikinya (Rasyid, 2019). Hal ini sesuai dengan fungsi dan tujuan dari pendidikan nasional di Indonesia yang telah diatur di dalam Undang-Undang No. 20 tahun 2003, yang menyatakan bahwa fungsi dari pendidikan itu adalah mengembangkan kemampuan dan membentuk watak serta peradaban bangsa yang bermartabat dalam rangka mencerdaskan kehidupan bangsa. Selain itu, pendidikan juga bertujuan untuk berkembangnya potensi peserta didik agar menjadi manusia yang beriman dan bertakwa kepada Tuhan Yang Maha Esa, berakhlak mulia, sehat, berilmu, cakap, kreatif, mandiri, dan menjadi warga negara yang demokratis serta bertanggung jawab (Rosyada, 2017).

Adapun tujuan dari penelitian ini adalah untuk mengetahui pemikiran Ibnu Sina tentang pendidikan, selain itu penelitian ini juga diharapkan mampu memberikan solusi alternatif terhadap berbagai macam permasalahan dalam dunia pendidikan sebagaimana yang telah dijelaskan di atas. Dari sekian banyak penelitian yang membahas tentang pemikiran pendidikan Ibnu Sina, kebanyakan dari penelitian-penelitian tersebut membahas mengenai konsep pendidikan Ibnu Sina secara keseluruhan, mulai dari tujuan pendidikan, kurikulum, metode, dan konsep pendidik. Dalam penelitian ini pun akan dijelaskan konsep pendidikan Ibnu Sina secara keseluruhan, namun yang membedakannya dengan penelitian yang lain yaitu penelitian ini akan lebih menekankan bagaimana sosok guru yang ideal dalam pandangan Ibnu Sina. Hal ini dikarenakan guru merupakan sentral dari pendidikan, guru yang memobilisasi semua kegiatan yang ada dalam proses pembelajaran, baik itu berupa tujuan, materi, metode, media yang akan digunakan, dan lain sebagainya.

Sudah jelas bahwasannya pendidikan diarahkan pada pengembangan potensi yang ada pada diri para peserta didik. Pendidikan bukan hanya sekedar transfer informasi tentang ilmu pengetahuan dari guru kepada murid semata, melainkan suatu proses pembentukan karakter, penanaman nilai-nilai yang baik, sehingga akan tercipta insan penerus bangsa yang berkualiatas, baik dari segi intelektual maupun moraralitasnya. Namun, pada kenyataannya, seiring dengan perkembangan zaman, tidak bisa dipungkiri bahwasanya ada beberapa dampak negatif dari perkembangan ilmu pengetahuan dan teknologi ini, salah satunya adalah terjadinya dekadensi moral atau kemerosotan akhlak dalam masyarakat, termasuk para pelajar yang nantinya akan menjadi generasi penerus bangsa. Dan ini merupakan salah satu tugas bagi lembaga pendidikan untuk memperbaiki dan mengevaluasi kembali seluruh komponen-komponen yang berhubungan dengan pendidikan, mulai dari kurikulum yang dipakai, tujuan pendidikan, metode yang dipakai, serta guru yang mengajar sudah memenuhi syarat sebagai pendidik atau belum. Dari beberapa 
komponen pendidikan tersebut, guru memiliki peranan yang cukup penting dalam penanaman nilai-nilai karakter dalam diri peserta didik. Baik dan buruknya kepribadian dan tingkah laku peserta didik banyak sedikitnya dipengaruhi oleh didikan dari pendidik tersebut. Untuk itu, dalam melakukan suatu kajian terhadap keberhasilan sistem pendidikan, khususnya dalam pembentukan dan penanaman nilai-nilai pada diri peserta didik, itu ditentukan kualitas dari pendidikan tersebut. Oleh karena itu, perlu adanya evaluasi dan pengembangan terkait sistem pendidikan, mulai dari kurikulum, tujuan, metode, media pengajaran, dan yang paling penting adalah kualitas dari pendidiknya. Konsep pendidikan menurut Ibnu Sina ini dapat menimbulkan dampak yang positif dalam dinamika keilmuan, serta dapat membantu dalam perbaikan dan pengembangan pendidikan kearah yang lebih baik lagi, karena pemikiran pendidikan menurut Ibnu Sina ini masih tetap relevan untuk dianalisis secara kritis hingga saat ini. Sehingga timbul pertanyaan, bagaimana konsep pendidikan dalam perspektif Ibnu Sina? Untuk menjawab pertanyaan tersebut, maka pada kesempatan ini penulis akan memaparkan dan membahasa secara khusus mengenai pandangan dan pemikiran Ibnu Sina yang terkait dengan pendidikan.

\section{METODE PENELITIAN}

Pendekatan yang digunakan dalam penelitian ini adalah pendekatan kualitatif. Pendekatan kualitatif ini merupakan pendekatan yang cenderung menggunakan kata-kata untuk menggambarkan dan menjelaskan data atau fenomena yang telah diperoleh (Nasution, 2020). Adapun metode yang digunakan dalam penelitian ini adalah metode kepustakaan atau library research. Studi pustaka atau library research ini merupakan serangkaian kegiatan yang berkenaan dengan metode pengumpulan data pustaka, membaca dan mencatat, serta mengolah bahan penelitian. Adapun teknik yang digunakan dalam metode penelitian ini yaitu dengan cara mengkaji buku-buku, jurnal, skripsi, makalah, atau sumber-sumber lainnya yang memiliki relevansi dengan penelitian ini (Supriyadi, 2017). Dalam peneltian ini, peneliti menggunakan teknik pengambilan data berdasarkan pada informasi yang dimuat dalam sumber-sumber literatur, baik yang berupa buku-buku maupun jurnal-jurnal yang relevan dengan tema penelitian. Adapun jurnal yang digunakan dalam penelitian ini sebanyak 21 jurnal dari rentang tahun 2014 - 2020. Sedangkan buku yang dipakai dalam penelitian ini berjumlah 2 buku dengan rentang tahun dari 2015 - 2017. Data-data yang sudah didapat kemudian peneliti analisis dengan menggunakan .metode deskriptif analisis, dimana peneliti mencoba memberikan gambaran secara jelas terkait dengan konsep pendidikan yang dikembangkan oleh Ibnu Sina, selain itu peneliti juga berusaha untuk mencoba menganalisnya dan membandingkannya dengan konsep pendidikan yang sedang berlangsung saat ini.

\section{HASIL DAN DISKUSI}

\subsection{Biografi Ibnu Sina}

Ibnu Sina atau juga dikenal dengan Avicenna bernama lengkap Abu 'Ali al-Husayn ibn Abdullah ibn Hasan ibn Ali ibn Sina (Gambar 1). Ia lahir pada bulan safar tahun $370 \mathrm{H} / 980 \mathrm{M}$ di Afshana (Kharmisin), sebuah kota kecil di dekat Bukhara, sekarang wilayah Uzbekistan (bagian dari Persia). Ayahnya bernama Abdullah, seorang sarjana terhormat penganut Syi'ah Ismai'illiyah, berasal dari Balkh Khorasan, suatu kota yang termasyhur di kalangan orang-orang Yunani dengan nama Bakhtra. Adapun ibunya bernama Astarah, berasal dari Afshana yang termasuk wilayah Afghanistan. Namun ada yang menyebutkan bahwa ibunya adalah orang yang berkebangsaan Persia, karena pada abad ke-10 M, wilayah Afghanistan ini termasuk daerah Persia (Iqbal, 2015).

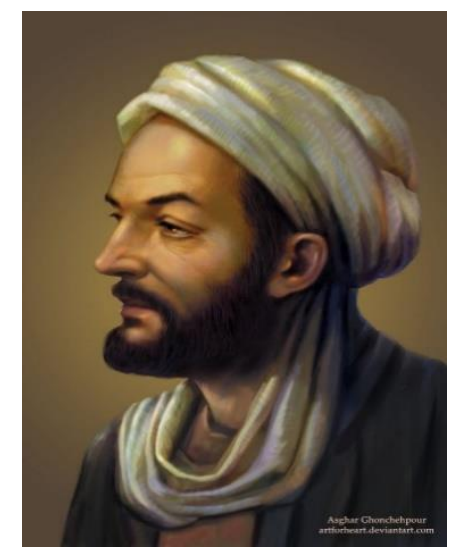

Gambar 1. Ibnu Sina (sumber: https://darunnajah.com/belajar-dari-ibnu-sina/)

Sejarah mencatat bahwa Ibnu Sina memulai pendidikannya pada usia 5 tahun di kota kelahirannya, Bukhara. Pengetahuan yang ia pelajari adalah al-Qur'an, setelah itu ia melanjutkan dengan mempelajari ilmu-ilmu agama Islam. Berkat ketekunan dan kecerdasannya, pada usia 10 tahun, Ibnu Sina telah berhasil menghafal al-Qur'an dan 'alim dalam berbagai ilmu keislaman yang berkembang pada saat itu, seperti tafsir, fiqh, kalam, filsafat, logika, dan pengobatan. Ketika berusia 17 tahun, Ibnu Sina telah memahami seluruh teori kedokteran yang ada dimasanya melebihi siapa pun juga. Karena kepintaran dan keahliannya itulah, ia diangkat sebagai konsultan dokter-dokter praktisi. Peristiwa ini terjadi setelah Ibnu Sina berhasil mengobati Pangeran Nuh Ibn Manshur, dimana sebelumnya tidak ada seorang tabib pun yang bias menyembuhkannya kecuali Ibnu Sina. Selain itu Ibnu Sina juga pernah diangkat menjadi Menteri oleh Sultan Syams al-Daulah yang berkuasa di Hamdan, karena berhasil mengobati penyakitnya.

Ibnu Sina mempelajari ilmu kedokteran secara otodidak dan mendalam, sehingga ia dikenal sebagai seorang dokter professional dan termasyhur pada zamannya. Hal ini didukung oleh kesengguhannya melakukan penelitian dan praktik mengobatan. Berkenaan dengan ini, ada sebagian yang mengatakan bahwa Ibnu Sina mempelajari kedokteran dari Ali bin Abi Sahl al-Masity dan Abi Mansur al-Hasan ibn Nuh al-Qomary (Iqbal, 2015). Kehebatan Ibnu Sina sebagai seorang dokter banyak dikenal sehingga ia diberikan kesempatan untuk mengobati Nuh Ibn Manshur, sultan Samanid di Bukhara sebagaimana yang telah 
dijelaskan di atas. Setelah berhasil mengobati Nuh Ibn Manshur, ia kemudian diberikan kesempatan untuk mempelajari buku-buku yang ada di perpustakaan istana. Ibnu Sina dengan kecerdasannya dapat menghafal sebagian besar buku-buku di perpustakaan tersebut yang kemudian ia jadikan modal awal untuk membuat karya pertamanya yang berjudul Hadiyah al-Ra'is ila al-Amir yang berisi tentang psikologi (Shofiyah, 2019). Berbagai ilmu pengetahuan yang Ibnu Sina pelajari dan kuasai di perpustakaan istana, termasuk di bidang filsafat. Namun, dalam mempelajari filsafat, terkadang Ibnu Sina memperoleh kesulitan. Pada beberapa penyelidikan yang membingungkan, ia meninggalkan buku-bukunya, mengambil air wudhu, lalu pergi ke masjid, dan terus shalat sampai hidayah menyelesaikan kesulitan-kesulitannya.

Ibnu Sina secara tekun melanjutkan kegiatan belajarnya dan menstimulasi perasaannya. Empat puluh kali dikatakan dia membaca metaphysics dari Aristoteles, sampai kata-katanya tertulis di dalam ingatannya, tetapi artinya tak dikenal, sampai suatu hari ia menemukan pencerahan dari uraian singkat al-Farabi. Dengan mengenal pemikiran al-Farabi, ia mengaku berhutang budi kepada al-Farabi. Sejak saat itu, Ibnu Sina tidak perlu lagi belajar secara 'meluas', tetapi hanya perlu meningkatkan pemahamannya secara 'mendalam' atas apa yang sudah dipelajari olehnya (Iqbal, 2015). Meskipun Ibnu Sina tidak secara langsung belajar kepada Al-Farabi, tetapi ia merasa memiliki utang budi karena dengan ulasan Al-Farabi telah banyak membantu Ibnu Sina dalam memahami metafisika Aristoteles (Shofiyah, 2019).

Ketika berusia 18 tahun, Ibnu Sina telah sibuk dengan urusan negara, memberi kuliah sebagai guru, menjadi filosof dan penyair serta menjadi seorang pengarang yang produktif dalam berbagai lapangan ilmu pengetahuan, seperti filsafat, kedokteran, kenegaraan, perbintangan, pasti, musik, bahasa, ukur, ketuhanan dan sebagainya. Bahkan tak kalah pentingnya konsep beliau tentang pendidikan (Azimah, 2016). Namun, keberhasilan Ibnu Sina tentunya tidak dapat dilepaskan dari peran seorang guru, diantara guru-gurunya adalah Abu 'Abdillah al-Natili dan Abu Muhammad Isma'il ibn al-Husyain. Kecerdasan Ibnu Sina membuatnya dapat menguasai ilmu-ilmu yang diberikan oleh guru-gurunya bahkan sampai melebihi gurunya sendiri (Iqbal, 2015). Karena keahliannya dalam berbagai bidang ilmu pengetahuan tersebut, sehingga beliau dikenal di dunia Barat dengan nama Avicenna dan mereka menyebutnya dengan "Aristoteles Baru”. Sedangkan di Arab dikenal dengan nama Syeikh al-Rais (Azimah, 2016).

Sebagai pemikiran inovatif dan kreatif pada umumnya, Ibnu Sina tidaklah terlepad dari cobaan yang menimpanya. Tatkala perpustakaan istana terbakar, musuh-musuhnya menuduh Ibnu Sina yang membakarnya supaya orang tidak bisa menguasai ilmu yang ada di sana, kecuali Ibnu Sina sendiri sehingga ia tidak tertandingi. Ia juga pernah dipenjarakan oleh putra al-Syam al-Daulah hanya karena ketidaksenangan atau kedengkiannya terhadap Ibnu Sina. Setelah beberapa bulan, Ibnu Sina dapat meloloskan diri dari penjara dan lari ke Isfahan yang kemudian disambut baik oleh Amirnya dengan kehormatan. Di kota ini, kemudian Ibnu Sina mengabdikan kiprahnya sebagai seorang intelektual muslim yang disegani. Ibnu Sina wafat pada usia 58 tahun, tepatnya pada tahun 980 H/1037 M di Hamadan, Iran, karena penyakit maag kronis yang dideritanya. Ia wafat ketika sedang mengajar di sebuah sekolah (Iqbal, 2015).

Ibnu Sina disamping sebagai seorang guru, filsuf, dan dokter, ia juga dikenal sebagai penulis yang produktif. Semasa hidupnya ia telah menghasilkan kurang lebih 267 karya (Shofiyah, 2019). Beberapa karya Ibnu Sina yang sangat terkenal diantaranya yaitu:

1. As-Syifa (The Book of Recorvery or The Book of Remedy), yakni buku yang membahas tentang penyambuhan. Buku ini dikenal di dalam bahasa latin dengan nama Sanatio atau Suffcienta. Seluruh buku ini terdiri dari 18 jilid, naskah selengkapnya dari buku As-Syifa sekarang tersimpan di Oxford University London. Buku ini mulai ditulis pada saat Ibnu Sina berusia 22 tahun (1022 M) dan berakhir pada tahun wafatnya yaitu pada saat berumur 58 tahun (1037 M). Isi dari buku ini terbagi atas 4 bagian, yaitu pertama, logika termasuk didalamnya retorika dan syair, meliputi dasar karangan Aristoteles tentang logika dan kemudian dimasukkan pula materi-materi dari penulis Yunani lainnya. Kedua, Fisika, termasuk psikologi, pertanian dan hewan. Adapun bagian-bagian dari fisika meliputi kosmologi, meteorology, udara, waktu, kekosongan, dan gambaran. Ketiga, matematika, bagian ini mengandung pandangan yang berpusat dari elemen-elemen Euclid, garis besar dari Almagest-nya Ptolemy, dan dan iktisar-iktisar tentang aritmatika dan ilmu musik. Keempat, metafisika yang didalamnya termasuk falsafah, pokok pikiran Ibnu Sina yang menggabungkan antara pendapat Aristoteles dengan elemen-elemennya Neo Platonic dan menyusun dasar percobaan untuk menyesuaikan ide-ide Yunani dan kepercayaan-kepercayaannya (Musdalifah, 2019).

2. Al-Najah (penyelamat), merupakan kitab yang memuat ringkasan dari buku As-Syifa. Buku An-Najah ini ditulis oleh Ibnu Sina untuk ditujukan kepada para pelajar yang ingin mempelajari dasar-dasar ilmu hikmah (filsafat). Di lain sisi, buku ini mengungkap dengan lengkap pemikiran Ibnu Sina tentang ilmu jiwa. Di dalam buku ini juga membahas tentang logika, fisika, dan metafisika yang ditulis sendiri oleh Ibnu Sina. Sedangkan yang membahas tentang matematika ditulis oleh Al-Juzjani. Jadi, buku An-Najah ini terdiri dari empat bagian sebagaimana yang telah disebutkan sebelumnya (Azhari, 2020).

3. Al-Qanun fi al-Thibb, sebuah karya ensiklopedi yang membahas tentang kedokteran. Karya ini menjadi buku pedoman pada universitas-univesitas di Barat sampai abad XVII. Keempat, Al-Isyarah wa al-Tanbihah (isyarat dan peringatan), sebuah karya yang membahas tentang logika dan hikmah, dan lain sebagainya (Shofiyah, 2019).

4. Al-Musiqa, karya ini merupakan karya yang membahas mengenai music

5. Danesh Nameh dan Uyun Al-Hikmah, yakni sebuah karya yang membahas mengenai filsafat

6. Mujis, Khabir wa Shagir, yakni sebuah buku yang menerangkan tentang dasar-dasar ilmu logika secara lengkap

7. Al-Hudud, yakni karangan atau buku yang berisikan istilah-istilah dan pengertian-pengertian yang dipakai di dalam ilmu filsafat

8. Al-Isyarat wa Tanbiehat, yakni karangan atau buku yang membicarakan terkait dalil-dalil dan peringatan-peringatan mengenai prinsip ke-Tuhan an dan keagamaan (Musdalifah, 2019).

9. Dan lain-lain.

\subsection{Konsep Pemikiran Ibnu Sina tentang Pendidikan}

Pendidikan adalah sesuatu yang esensial bagi manusia. Dengan Pendidikan, manusia bisa menghadapi alam semesta ini demi mempertahankan hidupnya. Karena pentingnya pendidikan, Islam menempatkan pendidikan pada kedudukan yang penting dan juga tinggi dalam doktrinnya (Suyadi, 2019). Sebagaimana dijelaskan di dalam QS. Al-Mujadalah ayat 11 berikut ini (Mardiah, 2019): 


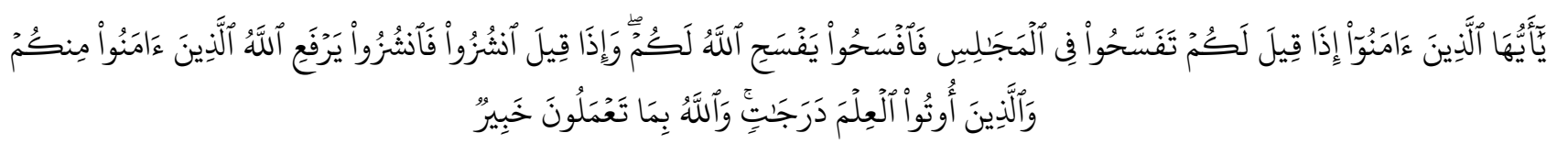

"Hai orang-orang beriman apabila dikatakan kepadamu: 'Berlapang-lapanglah dalam majlis', maka lapangkanlah, niscaya Allah akan memberi kelapangan untukmu. Dan apabila dikatakan: 'Berdirilah kamu', maka berdirilah, niscaya Allah akan meninggikan orang-orang yang beriman di antaramu dan orang-orang yang diberi ilmu pengetahuan beberapa derajat, dan Allah Maha Mengetahui apa yang kamu kerjakan." (QS. Al-Mujadalah: 11).

Pendidikan menempati posisi yang strategis dalam peningkatan kualitas dan kapasitas seseorang untuk mengarungi kehidupan (Musanna, 2017). Pendidikan bukan sekedar transfer informasi tentang ilmu pengetahuan dari guru kepada murid, melainkan suatu proses pembentukan karakter. Ada tiga misi utama pendidikan, yaitu pewarisan pengetahuan (transfer of knowledge), pewarisan budaya (transfer of culture), dan pewarisan nilai (transfer of value). Sebab itu pendidikan bisa dipahami sebagai suatu proses transformasi nilai-nilai dalam rangka pembentukan kepribadian dengan segala aspek yang dicakupnya (Syahidin, 2019). Menurut Ki Hadjar Dewantara, pendidikan merupakan suatu proses pemberian tuntunan untuk menumbuhkembangkan potensi anak (Musanna, 2017). Adapun tokoh Islam lain yang ikut berperan di dalam proses pendidikan Islam salah satunya adalah Ibnu Sina. Ibnu Sina adalah salah seorang di antara ahli falsafah pendidikan yang banyak meninggalkan pengaruh pada pemikiran pendidikan, sebagaimana pengaruh Plato, Aristoteles, Thomas Aquinas dan lainnya (Azimah, 2016).

Beragam latar belakang keilmuan yang dimiliki oleh Ibnu Sina dan profesinya yang pernah menjadi pendidik (guru) dan peserta didik memiliki andil yang cukup banyak dalam menuangkan berbagai pemikirannya tentang pendidikan. Artinya, pemikiran Ibnu Sina tentang pendidikan bukan hanya sekedar teori semata, melainkan juga praktik dari apa yang dialaminya ketika mendidik dan juga mengajar. Selain itu, ilmu yang dikuasainya pun turut membantu dalam pemikirannya tentang pendidikan. Adapun ilmu-ilmu yang turut membantu dalam pemikiran Ibnu Sina contohnya seperti ilmu filsafat Islam, ilmu iwa (psikologi), ilmu tasawuf, ilmu kedokteran, dan ilmu logika (Azhari, 2020). Menurut Ibnu Sina, ilmu itu terbagai menjadi dua bagian, yaitu ilmu yang tak kekal dan ilmu yang kekal (hikmah). Ilmu yang kekal dipandang dari perannya sebagai alat yang dapat disebut dengan logika. Akan tetapi, berdasarkan tujuannya, maka ilmu dapat dibagi menjadi ilmu yang praktis dan teoritis. Adapun yang termasuk ke dalam ilmu teoritis adalah ilmu kealaman, matematika, ilmu ketuhanan, dan ilmu kulli. Sedangkan yang termasuk ke dalam ilmu praktis diantaranya yaitu ilmu akhlak, ilmu pengurusan rumah, ilmu pengurusan kota, dan ilmu nabi (syari'ah) (Putra, 2015). Paling tidak ada empat point pemikiran filosofis Ibnu Sina dalam bidang pendidikan, yaitu tujuan pendidikan, konsep kurikulum pendidikan, konsep metode pembelajaran, dan konsep pendidik atau guru. Adapun penjelasan dari ke empat point pemikiran Ibnu Sina yang terkait dengan pendidikan adalah sebagai berikut:

\section{Tujuan Pendidikan}

Ibnu Sina mengatakan bahwa akal adalah sumber dari segala kejadian, di mana akal adalah satu-satunya keistimewaan manusia. Oleh karena itu, Ibnu Sina mengatakan bahwa akal itu wajib dikembangkan dan itulah sebenarnya tujuan akhir dari pendidikan (Aslamiyah, 2020). Ibnu Sina juga menerangkan, tujuan dari pendidikan itu mempunyai tiga fungsi yang kesemuanya bersifat normative. Pertama, tujuan itu menentukan haluan bagi proses pendidikan. Kedua, tujuan itu bukan hanya sekedar menentukan haluan yang dituju, melainkan juga sekaligus memberi rangsangan. Ketiga, tujuan itu adalah nilai, dan jika dipandang bernilai dan jika diinginkan, maka tentulah akan mendorong pa peserta didik untuk dapat mencapai tujuan dari pendidikan tersebut (Alwizar, 2015). Lebih lanjut, Ibnu Sina mengatakan bahwa tujuan pendidikan itu harus diarahkan pada pengembangan seluruh potensi yang dimiliki seseorang ke arah perkembangan yang sempurna, yaitu perkembangan fisik, intelektual dan budi pekerti dalam rangka menciptakan insan kamil. Di sisi lain, ia juga mengatakan bahwa tujuan pendidikan itu juga diarahkan pada upaya persiapan seseorang agar dapat hidup dalam masyarakat secara bersama-sama dengan melakukan pekerjaan atau keahlian yang dipilihnya sesuai dengan bakat, kesiapan, kecenderungan dan potensi yang dimiliki (Azimah, 2016). Dari penjelasan di atas, secara umum tujuan pendidikan menurut Ibnu Sina adalah tercapainya insan kamil, selain itu tujuan pendidikan juga diarahkan agar manusia dapat melaksanakan fungsi khalifah di masyarakat dengan baik (Shofiyah, 2019).

Adapun secara khusus, Ibnu Sina telah mengklasifikasikan tujuan-tujuan pendidikan ditinjau dari aspek jasmani, budi pekerti, dan keterampilan. Adapun tujuan pendidikan dari aspek jasmani adalah mencapai kebahagiaan peserta didik melalui kegiatan jasmani dan pembinaan fisik, seperti olahraga, makan, minum, tidur, dan menjaga kebersihan agar fisik dan kecerdasan otak peserta didik dapat tumbuh dan berkembang secara optimal. Sedangkan tujuan pendidikan dari aspek budi pekerti diarahkan untuk terbentuknya peserta didik yang memiliki akhlak yang baik yang dapat diterapkan kehidupan sehari-hari. Dan tujuan pendidikan dari aspek keterampilan diarahkan untuk mencapai peserta didik yang terampil dan memiliki keahlian dalam bidang tertentu agar dapat melaksanakan pekerjaan secara professional dengan keahlian yang dimiliki. Selain itu, menurut Ibnu Sina, tujuan utama dari pendidikan pada umumnya adalah pendidikan budi pekerti karena disamping membentuk kepribadian, pendidikan juga diarahkan untuk terbentuknya peserta didik yang berbudi pekerti. Maka dengan memperhatikan tujuan pendidikan yang dikemukakan oleh Ibnu Sina yang digolongkan kedalam beberapa aspek tersebut, dapat dimaknai bahwa Ibnu Sina sangat memperhatikan pengembangan potensi peserta didik secara seimbang, tidak hanya aspek pengetahuan dan keterampilan, namun juga aspek budi pekerti dan aspek jasmaniah. Tidak hanya itu, Ibnu Sina juga memposisikan pengembangan budi pekerti dan akhlak peserta didik sebagai suatu hal yang sangat penting, sebagai dasar pengembangan pengetahuan dan keterampilan (Shofiyah, 2019). Rumusan tujuan Pendidikan Ibnu Sina tampak mencerminkan sikapnya selain sebagai seorang pemikir, beliau juga merupakan pekerja dan praktisi sebagaimana yang telah terdapat di dalam dirinya (Musdalifah, 2019).

Khusus mengenai tujuan pendidikan untuk membentuk manusia yang memiliki akhlak mulia, Ibnu Sina mengemukakan bahwa ukuran akhlak mulia tersebut dijabarkan secara luas yang meliputi segala aspek kehidupan manusia. Adapun aspek-aspek kehidupan yang menjadi syarat bagi terwujudnya suatu sosok pribadi yang berakhlak mulia meliputi aspel kepribadian, social, dan spiritual. Ketiga aspek tersebut harus berfungsi secara integral dan komprehensif. Pembentukan akhlak mulia ini bertujuan untuk mencapai suatu kebahagiaan (sa'adah). Dari beberapa tujuan yang dikemukakan di atas, secara sederhana dapat disimpulkan bahwa tujuan pendidikan Islam menurut Ibnu Sina adalah mengembangkan potensi peserta didik secara optimal sehingga memiliki akal yang sempurna, akhlak yang mulia, sehat jasmani dan rohani, serta memiliki keterampilan yang sesuai dengan bakat dan minatnya, sehingga ia akan memperoleh kebahagiaan dalam hidupnya (Iqbal, 2015). 
Untuk mewujudkan tujuan pendidikan tersebut seorang pendidik harus mampu mengembangkan potensi dan bakat seseorang. Selain harus mengembangkan potensi dan bakat secara optimal, juga harus mampu menolong manusia agar bisa melaksanakan fungsinya sebagai khalifah di dunia ini. hal ini menunjukkan bahwa tujuan pendidikan seharusnya tidak hanya bisa mengembangkan potensi yang ada diri seseorang. akan tetapi bagaimana tujuan pendidikan itu harus bisa di implementasikan pada kehidupan masyarakat secara baik (Mukhlis, 2015). Sehingga, selain berkembangnya seluruh potensi yang ada pada diri peserta didik, mereka juga dapat mengaplikasikan ilmu yang mereka dapatkan melalui proses pendidikan kepada lingkungan masyarakat maupun dunia pekerjaan mereka. Hal ini sesuai dengan tujuan dari pendidikan saat ini, yakni mengembangkan potensi yang dimiliki oleh peserta didik dan juga mengembangkan keterampilan yang diperlukan oleh dirinya, masyarakat, bangsa dan Negara.

\section{Konsep Kurikulum Pendidikan}

Istilah kurikulum telah banyak dikemukan oleh para ahli pendidikan salah satu oleh Abdurrahman Al-Nahlawi, ia mengemukakan bahwa kurikulum merupakan seluruh program pendidikan yang di dalamnya mencakup masalah-masalah metode, tujuan, tingkat pengajaran, materi pelajaran setiap tahun ajaran, topik-topik pelajaran, serta aktivitas yang dilakukan setiap siswa pada setiap meteri pelajaran (Mukhlis, 2015). Adapun kurikulum menurut Crow adalah rancangan pengajaran yang isinya sejumlah mata pelajaran yang disusun secara sistematis yang diperlukan sebagai syarat untuk menyelesaikan suatu program pendidikan tertentu. Sedangkan menurut Ibnu Sina, kurikulum harus didasarkan kepada tingkat perkembangan usia peserta didik, yaitu fase 3-5 tahun, 6-14 tahun, dan di atas 14 tahun (Solihin, 2014), sebagaimana yang akan dijelaskan di bawah ini:

\section{a. Fase 3-5 tahun}

Pendidikan pada usia 3-5 tahun dapat disebut dengan pendiidkan usia dini. Menurut Ibnu Sina, pada jenjang usia ini mata pelajaran yang diberikan adalah olahraga, budi pekerti, kebersihan, seni suara, dan kesenian. Pelajaran olahraga tersebut diarahkan untuk membina kesempurnaan pertumbuhan fisik peserta didik dan berfungsinya organ tubuh secara optimal. Oelh sebab itu, pelajaran olahraga ini harus disesuaikan dengan tingkat perkembangan anak serta bakat yang dimilikinya. Jangan sampai seorang guru memberikan porsi olahraga yang berlebihan pada murid usia 3-5 tahun. Hal ini dikarenakan porsi yang tidak tepat hanya akan membahayakan keselamatan dari peserta didik (Nasution, 2020). Adapun pelajaran budi pekerti diarahkan untuk membekali peserta didik agar memiliki kebiasaan sopan santun dalam pergaulan hidup sehari-hari. Pelajaran budi pekerti ini sangat dibutuhkan dalam rangka membina kepribadian anak sehingga jiwanya menjadi suci dan terhindar dari perbuatan-perbuatan buruk yang dapat mengakibatkan jiwanya rusak dan sulit diperbaiki kelak pada usia dewasa. Dengan demikian, Ibnu Sina memandang bahwa pelajaran akhlak sangat penting ditanamkan kepada anak sejak usia dini (Iqbal, 2015). Selanjutnya, pendidikan kebersihan diarahkan agar peserta didik memiliki kebiasaan mencintai kebersihan. Ibnu Sina mengatakan bahwa pelajaran hidup bersih ini hendaknya dimulai dari sejak anak bangun tidur, ketika hendak makan, sampai saat ia akan tidur kembali (Nasution, 2020). Sedangkan dengan pendidikan seni suara dan kesenian, peserta didik diarahkan agar memiliki ketajaman perasaan dalam mencintai dan meningkatkan daya khayal peserta didik.

\section{b. Fase 6-14 tahun}

Kurikulum untuk anak usia 6-14 tahun di dalamnya mencakup pelajaran membaca dan menghafal al-Qur'an, agama, syair, dan pelajaran olahraga. Pelajaran membaca dan menghafal berguna di samping untuk mendukung pelaksanaan ibadah yang memerlukan bacaan ayat-ayat al-Qur'an seperti shalat, juga untuk mendukung keberhasilan dalam mempelajari agama Islam, seperti pelajaran tafsir al-Qur'an, fiqh, tauhid, akhlak, dan pelajaran agama lainnya yang sumber utamanya adalah al-Qur'an (Solihin, 2014). Menurut catatan sejarah, Ibnu Sina telah mampu membaca al-Qur'an sejak usia 10 tahun. Oleh karena itu, materi menghafal al-Qur'an ini sudah bisa diberikan pada anak usia 6-14 tahun, hal ini dilakukan untuk melatih kemampuan menghafal dan kognitif para peserta didik (Aslamiyah, 2020).

Pelajaran syair dibutuhkan pada usia ini sebagai lanjutan dari pelajaran seni pada tingkat sebelumnya. Di samping petunjuk al-Qur'an dan Sunnah, peserta didik perlu menghafal syair-syair yang mengandung nilai-nilai pendidikan dalam menuntun perilakunya. Sedangkan pelajaran olahraga harus disesuaikan dengan tingkatan usia peserta didik. Porsi dan jenis olahraga yang diajarkan kepada anak usia 6 tahun boleh jadi berbeda dengan anak yang usianya telah mencapai 14 tahun (Nasution, 2020). Oleh karena itu, seoran pendidik hendaknya mengetahui dan memahami dengan pasti kondisi fisik dari setiap para peserta didiknya.

Berdasarkan hal di atas, jika pada usia 3-5 tahun anak lebih ditekankan pada aspek afektif atau pendidikan akhlak, maka pada usia 6-14 tahun anak telah diberikan pelajaran yang menyentuh aspek kognitif. Bahkan pada usia ini anak telah diajarkan membaca al-Qur'an, menghafal, dan memahami tata bahasanya.

\section{c. Fase 14 tahun ke atas}

Menurut Ibnu Sina, pada usia 14 tahun ke atas, peserta didik mesti memperoleh mata pelajaran yang berbeda dari tingkatan usi sebelumnya. Dalam hal ini mata pelajaran yang diberikan mesti dirumuskan berdasarkan atas pertimbangan minat dan bakat para peserta didik (Nasution, 2020). Jadi, pada usia ini, peserta didik diarahkan untuk menguasai suatu bidang ilmu tertentu (spesialisasi bidang keilmuan) (Iqbal, 2015). Strategi penyusunan kurikulum yang ditawarkan oleh Ibnu Sina didasarkan pada pemikiran yang bersifat pragmatis fungsional, yakni dengan melihat segi kegunaan dari ilmu dan keterampilan yang dipelajari dengan tuntutan masyarakat. Dengan cara demikian, setiap lulusan pendidikan akan siap difungsikan dalam berbagai lapangan pekerjaan yang ada di masyarakat.

Selain mengklasifikasikan kurikulum berdasarkan tingkat usia peserta didik, Ibnu Sina juga mengklasifikasikan mata pelajaran menjadi dua bagian, yaitu mata pelajaran yang masuk dalam ilmu teoritis dan mata pelajaran yang masuk dalam ilmu praktis. Ilmu teoritis meliputi ilmu tabi'i yang mencakup ilmu kedokteran, astrologi, ilmu firasat, ilmu sihir (tilsam), ilmu tafsir mimpi, ilmu niranjiyat, dan ilmu kimia. Selain ilmu tabi'i, yang termasuk ke dalam ilmu teoritis adalah ilmu matematika, dan ilmu ketuhanan. Ilmu ketuhanan ini disebut ilmu yang paling tinggi, yang mencakup ilmu tentang cara-cara terunnya wahyu, hakikat jiwa pembawa wahyu, mu'jizat, berita gharib, ilham, dan ilmu tentang kekekalan ruh, dan sebagainya. Sedangkan yang termasuk ke dalam ilmu praktis meliputi, ilmu akhlak, ilmu berumah tangga, dan ilmu politik, terutama dalam kehidupan bermasyarakat yang menginginkan tegaknya keadilan dengan menetapkan undang-undang dan syari'at (Iqbal, 2015). Adapun ciri-ciri dari konsep kurikulum Ibnu Sina adalah sebagai berikut (Shofiyah, 2019): 
a. Penyusunan kurikulum yang dilakukan Ibnu Sina sangat memperhatikan psikologi peserta didik, dimana kurikulum yang disusunnya didasarkan pada tahap perkembangan peserta didik.

b. Konsep kurikulum Ibnu Sina berusaha mengembangkan aspek jasmani, akhlak dan intelektual peserta didik secara secara seimbang berdasarkan tahap perkembangan usianya.

c. Bersifat pragmatis fungsional, dimana kurikulum diarahkan untuk dapat mengembangkan potensi peserta didik sehingga menghasilkan lulusan yang dapat memenuhi kebutuhan masyarakat atau pasar dengan bidang keahlian yang dimilikinya.

d. Konsep kurikulum berlandaskan pada al-Qur'an dan Sunnah sehingga peserta didik memiliki iman, ilmu, dan amal secara terpadu.

e. Berbasis akhlak, kurikulum yang disusun sangat memperhatikan pendidikan akhlak

\section{Konsep Metode Pembelajaran}

Metode pembelajaran memiliki peran penting dalam mencapai tujuan pembelajaran. Ibnu Sina memandang bahwa penggunaan metode pembelajaran harus disesuaikan dengan karakteristik materi pembelajaran agar tidak kehilangan daya relevansinya. Menurut Abudinnata, ada beberapa metode pendidikan yang ditawarkan oleh Ibnu Sina, yaitu:

a. Talqin, metode ini digunakan dalam pelajaran membaca alQur'an dengan cara memperdengarkan bacaan al-Qur'an kepada peserta didik secara bertahap. Setelah itu pesrta didik diminta untuk mendengarkan dan mengulangi bacaan tersebut secara perlahan-lahan dan dilakukan berulang-ulang hingga akhirnya peserta didik hafal (Iqbal, 2015). Menurut Ibnu Sina, metode talqin ini dapat pula ditempuh dengan cara seorang pendidik meminta bantuan kepada para peserta didiknya yang sudah agak pandai untuk membimbing teman-temannya yang masih tertinggal. Cara seperti ini dalam ilmu Pendidikan modern disebut dengan metode tutor sebaya sebagaimana dikenal dalam pengajaran dengan modul (Musdalifah, 2019).

b. Demonstrasi, metode ini dapat digunakan dalam pembelajaran yang bersifat praktik, seperti cara mengajar menulis. Dalam menggunakan metode ini, terlebih dahulu seorang guru hendaknya mencontohkan terlebih dahulu tulisan huruf-huruf hijaiyyah di hadapan peserta didik dan kemudian peserta didik disuruh untuk mendengarkan pengucapan huruf hijaiyyah sesuai dengan makhrajnya, dan dilanjutkan dengan mendemonstrasikan cara penulisan huruf hijaiyyah tersebut (Solihin, 2014).

c. Keteladanan dan Pembiasaan, Ibnu Sina berpendapat bahwa pembiasaan termasuk ke dalam metode pembelajar yang paling efektif, khususnya dalam mengajarkan akhlak. Beliau mengakui bahwa adanya pengaruh mengikuti atau meniru dan memberikan tauladan yang baik dalam proses pendidikan dikalangan anak pada usia dini. Hal ini dikarenakan secara thabi'iyah anak mempunyai kecenderungan untuk mengikuti dan meniru segala sesuatu yang dilihat, dirasakan, dan didengarnya. Oleh karena itu, di dalam pergaulan pun, seorang anak hendaknya diharapkan berinteraksi dengan anak-anak yang mempunyai akhlak yang baik (Musdalifah, 2019).

d. Diskusi, metode ini dilakukan dengan cara guru memaparkan suatu masalah dalam suatu pelajaran yang dapat berupa pertanyaan yang bersifat problematis untuk dibahas dan dipecahkan bersama oleh peserta didik. Metode ini untuk mengajarkan pengetahuan yang bersifat rasional dan teoretis.

e. Magang, metode ini digunakan agar peserta didik dapat menggabungkan antara teori dan praktik, dimana para peserta didik diminta untuk mempraktikkan teori yang telah didapatkannya. Metode ini akan membuat peserta didik mahir dalam bidang ilmu yang digelutinya dan juga akan mendatangkan keahlian dalam bekerja.

f. Penugasan, metode ini dilakukan dengan cara guru menyiapkan dan memberikan modul kepada peserta didik untuk dipelajarinya (Shofiyah, 2019). Metode penugasan ini pernah dilakukan oleh Ibn Sina dengan menyusun sejumlah modul atau naskah kemudian menyampaikannya kepada para muridnya untuk dipelajarinya (Solihin, 2014). Cara ini ia lakukan kepada salah seorang peserta didiknya yang bernama Abu Ar-Raihan Al-Biruni dan Abi Husain Ahmad As-Suhaili. Dalam bahasa Arab, pengajaran dengan penugasan ini dikenal dengan istilah at ta'lim bi al marasil (pengajaran dengan mengirimkan sejumlah naskah atau modul) (Rasyid, 2019).

g. Targhib dan Tarhib, metode ini dalam pendidikan modern dikenal dengan istilah reward dan punishment. Istilah reward memiliki arti ganjaran, hadiah, penghargaan atau imbalan dan merupakan salah satu alat pendidikan yang berbentuk reinforcement yang positif, sekaligus sebagai motivasi yang baik (Iqbal, 2015). Meskipun Ibnu Sina telah memberikan penjelasan mengenai metode punishment (hukuman), namun Ibnu Sina lebih mengutamakan pada pemberian dorongan dan pujian kepada peserta didik yang menurutnya akan lebih berdampak positif karena rasa salah, penyesalan, dan perasaan berdosa peserta didik dapat dihapus dengan pujian dari seorang guru daripada pemberian hukuman (Shofiyah, 2019). Pada dasarnya, mengenai konsep hukuman dalam proses pembelajaran, Ibnu Sina tidak berkenaan menggunakan hukuman. Hal ini didasarkan pada sikapnya yang sangat menghargai martabat manusia. Namun, Ibnu Sina membolehkan hukuman tersebut, apabila dalam keadaan terpaksa dan dilakukan dengan cara yang sangat berhati-hati. Dalam melakukan hukuman terhadap peserta didik, sebaiknya diberikan peringatan dan ancaman terlebih dahulu, jangan menindak anak dengan kekerasan, tetapi dengan kehalusan hati, lalu diberi motivasi dan persuasi dan kadang-kadang dengan muka masam atau dengan puji-pujian, sehingga anak terodong untuk melakukan kebaikan (Azimah, 2016).

Dari beberapa metode yang diuraikan di atas, hal tersebut menunjukkan bahwa Ibnu Sina memberikan perhatian yang serius terhadap Pendidikan. Terdapat empat karakteristik metode yang ditawarkan oleh Ibnu Sina, diantaranya yaitu: Pertama, pemilihan dan penerapan metode harus disesuaikan dengan karakteristik materi pelajaran. Kedua, metode juga diterapkan dengan mempertimbangkan psikologis peserta didik, termasuk di bakat dan minat peserta didik. Ketiga, metode yang ditawarkan tidaklah kaku, akan tetapi dapat berubah sesuai dengan kondisi dan kebutuhan peserta didik (metode bersifat fleksibel). Keempat, ketepatan dalam memilih dan menerapkan metode sangat menentukan keberhasilan pembelajaran (Rasyid, 2019).

Metode-metode di atas tentunya tidak digunakan secara terpisah sama sekali, akan tetapi perlu dikombinasikan dengan metode yang lain. Misalnya penggunaan metode ceramah, bukan berarti dalam suatu pembelajaran hanya menggunakan metode ceramah saja, namun perlu dikombinasikan dengan metode yang lain seperti keteladanan, diskusi, dan lain-lain. Dalam memilih metode pembelajaran, seorang guru diharuskan untuk memahami karakteristik materi, keadaan peserta didik, dan melaksanakan pembelajaran yang luwes sehingga metode yang digunakan dapat mendukung tercapainya tujuan pembelajaran (Shofiyah, 2019). Karena, tercapai tidaknya suatu tujuan dari pembelajaran itu sangat ditentukan oleh bagaimana cara guru tersebut menyampaikan 
pembelajaran dan nilai-nilai yang terkandung di dalam materi tersebut, sehingga nantinya dapat diaplikasikan di dalam kehidupan sehari-hari.

Di dalam setiap proses pembelajaran, setiap guru atau pendidik tentu menginginkan para peserta didiknya dapat memahami dengan baik terkait materi yang ia ajarkan. Untuk mencapai hal tersebut, diperlukan kekreatifan dari seorang guru dalam mengelola dan mengemas materi pembelajaran tersebut agar menjadi menarik dan menyenangkan. Pembelajaran yang sesungguhnya itu adalah suatu proses yang menekankan pada pengembangan cara atau metode dan rekayasa sumber belajar atau media sehingga benar-benar mampu menumbuhkan semangat dan kreativitas peserta didik untuk melakukan kegiatan belajar secara mandiri (Abdussalam, 2017). Oleh karena itu, seorang pendidik hendaknya menguasai berbagai macam metode pembelajaran dan mengaplikasikannya di dalam kelas sesuai dengan tingkat perkembangan para peserta didik. Dengan adanya metode pembelajaran ini akan memudahkan pendidik dalam menyampaikan materi yang disampaikan, selain itu suasana pembelajaran pun akan lebih hidup dan menyenangkan, sehingga tujuan dari pembelajaran tersebut akan mudah tercapai.

Mengapa seorang guru atau pendidik harus mengetahui dan menguasai berbagai macam metode pembelajaran? Hal ini dikarenakan dalam suatu kelas, setiap peserta didik memiliki gaya belajar yang berbeda antara satu dengan yang lainnya, ada yang gaya belajarnya menggunakan penglihatan (visual) pendengaran (audio), dan gabungan antara keduanya, yakni dengan cara melihat dan mendengarkan (audio visual). Selain itu, setiap peserta didik juga mempunyai daya kemampuan yang berbeda-beda dalam memahami dan menyerap materi pembelajaran yang disampaikan. Ada yang cepat dan mudah dalam memahami pelajaran dan ada juga yang lama dan susah dalam memahami pelajaran. Ini merupakan salah satu tugas yang harus diselesaikan oleh setiap pendidik. Salah satu cara yang dapat dilakukan oleh para pendidik dalam menghadapi persoalan tersebut adalah dengan cara memahami kaya belajar dan karakteristik serta kemampuan dari para peserta didik, kemudian dilanjutkan dengan pemilihan dan penggunaan media serta metode pembelajaran yang sesuai dengan kondisi para peserta didik dan jura relevan dengan materi pembelajaran. Dengan mengetahui gaya belajar, karakteristik, serta kemampuan dari para peserta didik, maka para pendidik akan lebih mudah dalam menyiapkan media dan metode yang akan digunakan dalam menyampaikan pembelajaran yang sesuai dengan kebutuhan para peserta didiknya. Oleh karena itu, seorang pendidik hendaknya selalu belajar dan meng-upgrade kemampuannya sesuai dengan perkembangan zaman, mulai dari meng-upgrade kemampuan intelektualnya hingga menguasai dan belajar berbagai macam metode dan strategi pembelajaran yang sesuai dengan kondisi perkembangan para peserta didiknya di setiap zaman.

\section{Konsep Pendidik atau Guru}

Dalam proses pembelajaran, seorang pendidik atau guru mempunyai peranan yang cukup penting dalam rangka memobilisasi semua kegiatan yang ada dalam proses pembelajaran, baik itu berupa tujuan, materi, metode dan sebagainya. Tanpa adanya guru sangat mustahil proses pembejaran dapat berjalan dengan sempurna. Dalam Kamus Umum Bahasa Indonesia, pendidik artinya orang yang mendidik. Adapun dalam bahasa arab, pendidik dikenal dengan sebutan al-mualim, murabbi, mudarris, dan juga ustadz. Berdasarkan Undang-Undang Nomor 14 tahun 2005 pasal 1 ayat 1 tentang Guru dan Dosen, menyatakan bahwa guru adalah pendidik profesional dengan tugas utama mendidik, mengajar, membimbing, mengarahkan, melatih, menilai, dan mengevaluasi peserta didik pada pendidikan anak usia dini jalur pendidikan formal, pendidikan dasar, dan pendidikan menengah.

Menurut Ahmad Tafsir, pendidik dalam Islam adalah orang yang bertanggung jawab terhadap perkembangan peserta didik dengan upaya mengembangkan seluruh potensi yang ada di dalam diri peserta didik, baik itu potensi afektif (rasa), kognitif (cipta), maupun psikomotorik (karsa). Sedangkan Abdul Mujib mengemukakan bahwa pendidik adalah bapak rohani (spiritual father) bagi peserta didik, yang memberikan santapan jiwa dengan ilmu, pembinaan akhlah mulia, dan meluruskan perilakunya yang buruk (Ramli, 2015). Adapun konsep pendidik atau guru yang ditawarkan oleh Ibnu Sina adalah tentang guru yang baik. Ibnu Sina mengatakan bahwa guru yang cakap adalah guru yang berakal cerdas, beragama, mengetahui cara mendidik akhlak, cakap dalam mendidik anak, berpenampilan tenang, jauh dari berolokolok dan main-main dihadapan muridnya, tidak bermuka masam, sopan, santun, dan bersih (Azimah, 2016). Guru dalam pandangan Ibnu Sina haruslah dapat menjadi teladan bagi peserta didiknya karena peserta didik biasanya meniru berbagai hal dari gurunya, misalnya perkataan, perbuatan, dan gaya hidupnya. Menurut Ibnu Sina, seorang guru itu seyogyanya adalah seseorang yang berakal sehat, kuat agamanya, berakhlak mulia, pandai mengambil hati peserta didik, berwibawa, berkepribadian yang tangguh, berwawasan yang luas dan tidak statis, manis tutur katanya, cerdik, terpelajar, dan berhati suci. Di samping itu, seorang guru haruslah orang yang mendalam ilmu pengetahuan agamanya, seorang yang shaleh dan bertaqwa kepada Allah SWT., dan rasul-Nya. Seorang guru harus merasa takut melakukan perbuatan yang dilarang oleh Allah SWT., baik itu diketahui oleh orang lain atau tidak. Itulah sebabnya dalam mendidik para peserta didik diperlukan pengalaman dan penelitian secara mendalam serta persiapan khusus, di samping etika dan tata krama lahiriah yang baik (A'yuni, 2020).

Ibnu Sina juga menambahkan bahwa seorang guru hendaknya menonjol budi pekertinya, cerdas, teliti, sabar, telaten dalam membimbing anak-anak, adil, hemat dalam penggunaan waktu, gemar bergaul dengan anak-anak, tidak keras hati dan senantiasa menghias diri. Selain itu, seorang guru juga harus mengutamakan kepentingan ummat daripada kepentingan diri sendiri, menjauhkan diri dari meniru sifat raja dan orang-orang yang berakhlak tercela, mengetahui etika dalam majelis ilmu, sopan dan santun dan berdebat, berdiskusi dan bergaul. Ibnu Sina juga menekankan agar seorang guru tidak hanya mengajarkan dari segi teoritis saja, melainkan juga melatih keterampilan, merubah budi pekerti, dan kebebasan dalam berfikir para peserta didiknya. Ia juga menekankan hendaknya ada perhatian yang seimbang antara aspek penalaran (kognitif), penghayatan (afektif), dan pengamalan atau praktek (psikomotorik) (Rasyid, 2019).

Berdasarkan uraian di atas, nampak jelas bahwa guru yang ideal dalam pandangan Ibnu Sina tidak cukup hanya memiliki ilmu dan wawasan yang luas, tetapi juga harus memiliki akhlak yang baik dan hati yang tulus (Shofiyah, 2019). Karena dengan kompetensi dan kepribadian yang baik tersebut, seorang guru akan dapat mencerdaskan para peserta didik dengan berbagai pengetahuan dan akhlak yang baik dalam rangka membina mental peserta didiknya.

Dalam Islam, tugas seorang pendidik dipandang sebagia sesuatu yang sangat mulia. Posisi ini menyebabkan Islam mengangkat derajat orang-orang yang beriman dan berilmu pengetahuan. Hal ini sesuai dengan firman Allah dalam QS. Al-Mujadalah/58 ayat 11: 


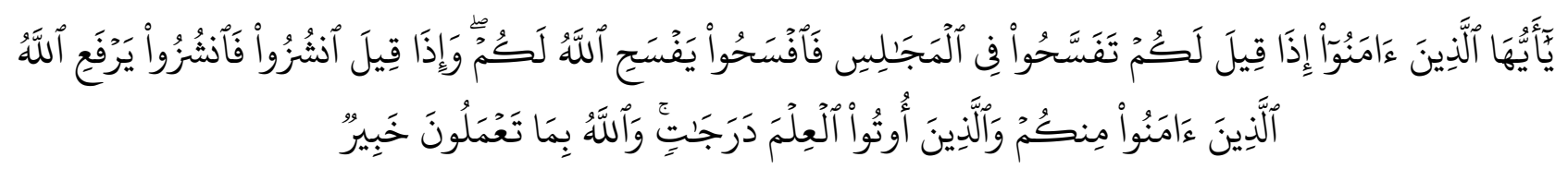

"Hai orang-orang yang beriman, apabila dikatakan kepadamu: "Berlapang-lapanglah dalam majelis", maka lapangkanlah, niscaya Allah akan memberi kelapangan ntukmu. Dan apabila dikatakan: "Berdirilah kamu, maka berdirilah, niscaya Allah akan meninggikan orang-orang yang beriman diantaramu dan orang-orang yang diberi ilmu pengetahuan beberapa derajat. Dan Allah Maha Mengetahui apa yang kamu kerjakan". (QS. Al-Mujadalah: 11) (Mardiah, 2019).

Ayat di atas menjelaskan bahwasanya Allah akan mengangkat derajat dari orang-orang yang beriman dan juga orang-orang yang memiliki pengetahuan. Secara tidak langsung ayat di atas menyuruh manusia untuk mengembangkan berbagai potensi yang ada di dalam dirinya melalui proses pendidikan, baik itu pendidikan formal dan juga pendidikan non-formal. Salah satu faktor yang membantu dalam berlangsungnya pendidikan adalah pendidik. Berdasarkan ayat di atas, dijelaskan bahwa tugas seorang pendidik merupkan tugas yang sangat mulia, baik dalam pandangan manusia maupun dalam pandangan Allah. Hal ini dikarenakan pendidik merupakan orang yang memiliki banyak ilmu yang hendak diajarkan kepada mereka yang membutuhkan. Menurut Al-Ghazali dalam (Shabir, 2015), seorang pendidik selain harus memiliki pengetahuan yang luas, mereka juga harus memiliki akhlak yang baik karena peserta didik selalu melihat dan meniru perilaku yang dilakukan oleh para pendidiknya. Karena teacher is the ideal figure in student life. He is an example and role model who are always remembered in the life of his student (Syahidin, 2019).

Tugas dan tanggung jawab seorang guru sebagai pendidik pada dasarnya bukan hanya sekedar mentransfer ilmu, mengajar, atau menyampaikan kewajiban kepada peserta didik semata, melainkan juga membimbing mereka secara keseluruhan, baik dari segi pengetahuan, sikap, keterampilan dan lainnya sehingga terbentuk kepribadian seorang muslim yang sesuai dengan ajaran Islam. Mereka mendidik, membimbing, mengarahkan, dan mengantarkan peserta didik menuju gerbang kesuksesan baik di dunia maupun di akhirat dengan disiplin ilmu yang dimilikinya. Bukan hanya pengetahuan saja yang diajarkan dan diberikan, akan tetapi nilai-nilai sosial dan nilai-nilai baik lainnya pun harus ikut ditanamkan ke dalam diri peserta didik. Kepribadian dan perilaku peserta didik akan menjadi baik apabila seorang guru mendidiknya dengan didikan yang baik, yakni dengan cara memberikan contoh dan teladan yang baik, mulai dari ucapannya, perbuatannya, pemikiran dan bahkan cara berpakaiannya pun dapat ditiru oleh para peserta didiknya. Hal ini dikarenakan guru pada hakekatnya digugu dan ditiru oleh peserta didiknya. Sehingga, apabila yang diajarkan dan dicontohkan kurang baik dan termasuk ke dalam perbuatan tercela, maka secara tidak langsung kepribadian dan perilaku peserta didik akan kurang baik pula. Sehingga dapat disimpulkan bahwa baik dan buruknya perilaku dan sikap dari peserta didik, sedikit banyaknya dipengaruhi oleh didikan dari gurunya.

Dari uraian di atas, diketahui bahwa seorang guru merupakan salah satu faktor utama yang mendorang dan membantu dalam menciptakan generasi penerus bangsa yang berkualitas, yakni generasi yang memiliki ilmu pengetahuan yang luas, keterampilan yang hebat, serta memilki perilaku dan moralitas yang baik. Oleh karena itu, guru atau pendidik ini merupakan faktor yang sangat penting dan berpengaruh dala proses pendidikan. Tanpa adanya seorang guru atau pendidik, proses pendidikan tidak akan berjalan dengan sempurna. Diibaratkan sebuah bangunan, apabila salah satu tiangnya hilang, maka bangunan tersebut tidak akan bisa berdiri dengan kokoh dan lambat laun akan roboh. Begitupun peran seorang guru/pendidik di dalam pendidikan.

\section{KESIMPULAN}

Berdasarkan uraian di atas, dapat disimpulkan bahwa terdapat empat konsep pendidikan dari Ibnu Sina, yakni konsep tujuan pendidikan, konsep kurikulum, konsep metode pengajaran, dan konsep pendidik. Selain itu, Ibnu Sina juga lebih menekankan kepada tercapainya insan kamil, dan juga agar manusia dapat melaksanakan fungsi khalifah di masyarakat dengan baik. Adapun tujuan pendidikan menurut Ibnu Sina harus diarahkan pada pengembangan seluruh potensi yang dimiliki seseorang ke arah perkembangan yang sempurna, yaitu perkembangan fisik, intelektual dan juga perkembangan budi pekerti. Sedangkan dalam menentukan kurikulum pendidikan hendaknya disesuaikan dengan perkembangan usia peserta didik. Strategi penyusunan kurikulum yang ditawarkan oleh Ibnu Sina didasarkan pada pemikiran yang bersifat pragmatis fungsional, yakni dengan melihat segi kegunaan dari ilmu dan keterampilan yang dipelajari dengan tuntutan masyarakat. Dimana setiap lulusan pendidikan akan siap difungsikan dalam berbagai lapangan pekerjaan yang ada di masyarakat.

Ibnu sina juga berpendapat bahwa di dalam proses pembelajaran hendaknya seorang guru menguasai berbagai metode pembelajaran, dan penggunaan metode pembelajaran tersebut harus relevan dengan materi yang hendak disampaikan. Selain itu, Ibnu Sina juga berpendapat bahwa guru yang baik itu adalah guru yang berakal cerdas, beragama, mengetahui cara mendidik akhlak, cakap dalam mendidik anak, berpenampilan tenang, jauh dari berolokolok dan main-main dihadapan muridnya, tidak bermuka masam, sopan, santun, dan bersih. Hal ini dikarenakan seorang guru itu merupakan contoh dan teladan yang baik bagi para peserta didiknya.

\section{Referensi}

Abdussalam, A. (2017). Pembelajaran Dalam Islam: Konsep Ta'lim Dalam Al-Qur'an. Yogyakarta: Maghza Puataka.

A'yuni, S. Q. (2020). Analisis Pemikiran Pendidikan Menurut Ibnu Sina dan Kontribusinya Bagi Pendidikan Islam di Era Modern.

Journal of Islamic Education Research, 1(03), 226-238.

Alwizar. (2015). Pemikiran Pendidikan Ibnu Sina. An-Nida: Jurnal Pemikiran Islam, 40(1), 191-201.

Aslamiyah, D. S. \& R. (2020). Konsep Pendidikan Dalam Perspektif Pemikiran Ibnu Sina. Al-Muaddib: Jurnal Ilmu-Ilmu Sosial Dan Keislaman, 5(1), 87-95.

Azhari, J. R. \& A. (2020). Pemikiran Ibnu Sina Tentang Pendidikan Anak. Zuriah (Jurnal Pendidikan Anak Usia Dini), 1(1), 49-66.

Azimah. (2016). Konsep Pendidikan dalam Perspektif Pemikiran Ibnu Sina. Fitra, 2(2), 69-80.

Baiturrahman, B. (2018). Pendidikan Islam Dalam Menghadapi Dekadensi Moral Di Era Globalisasi (Telaah: Pemikiran Muhammad

Tholhah Hasan) (Vol. 53, Issue 9). 
Hidayat, T., Rizal, A. S., \& Fahrudin, F. (2018). Pendidikan Dalam Perspektif Islam Dan Peranannya Dalam Membina Kepribadian Islami. Jurnal Mudarrisuna: Media Kajian Pendidikan Agama Islam, 8(2), 218.

Iqbal, A. M. (2015). Pemikiran Pendidikan Islam (Gagasan-Gagasan Besar Para Ilmuan Muslim. Yogyakarta: Pustaka Pelajar.

Iskarim, M. (2016). Dekadensi Moral Di Kalangan Pelajar (Revitalisasi Strategi PAI Dalam Menumbuhkan Moralitas Generasi Bangsa). Edukasia Islamika, 1(1), 1-20.

Mardiah. (2019). Tujuan Pendidikan Dalam Al-Qur'an. Jurnal Al-Liqo, 04(1), 90-107.

Mukhlis. (2015). Pemikiran Pendidikan Ibnu Sina dan Implementasinya di Era Globalisasi. Jurnal Kariman, 03(20), 49-64.

Musanna, A. (2017). Indigenisasi Pendidikan: Rasionalitas Revitalisasi Praksis Pendidikan Ki Hadjar Dewantara. Jurnal Pendidikan Dan Kebudayaan, 2(1), 117.

Musdalifah. (2019). Konsep Pendidikan Ibnu Sina tentang Tujuan Pendidikan, Kurikulum, Metode Pembelajaran, dan Guru. Rumah Jurnal UIN Alauddin Makassar, 8(2), 779-790.

Nasution, H. A. (2020). Pendidikan Karakter Perspektif Ibnu Sina. Al-Ikhtibar: Jurnal Ilmu Pendidikan, 7(1), 598-611.

Putra, A. T. A. (2015). Pemikiran Filosofis Pendidikan Ibnu Sina dan Implikasinya Pada Pendidikan Islam Kontemporer. Lliterasi, $\operatorname{VI}(2), 191-201$.

Ramli, M. (2015). Hakikat Pendidik Dan Peserta Didik. Tarbiyah Islamiyah, 5(1), 61-85.

Rasyid, I. (2019). Konsep Pendidikan Ibnu Sina tentang Tujuan Pendidikan, Kurikulum, Metode Pembelajaran, dan Guru. Ekspose: Jurnal Penelitian Hukum Dan Pendidikan, 18(1), 779-790.

Rosyada, D. (2017). Madrasah dan Profesionalisme Guru (Dalam Arus Dinamika Pendidikan Islam di Era Otonomi Daerah). Jakarta: UIN Jakarta Press.

Shabir, M. (2015). Kedudukan Guru Sebagai Pendidik: (Tugas dan Tanggung Jawab, Hak dan Kewajiban, dan Kompetensi Guru). Jurnal Auladuna, 2(2), 1150-1153.

Shofiyah, M. I. R. \& N. (2019). Relevansi Pemikiran Pendidikan Ibnu Sina Pada Pendidikan Masa Kini. Tarbawy: Indonesian Journal of Islamic Education, 6(2), 142-156.

Solihin. (2014). Konsep Pendidikan Islam Menurut Persfektif Ibnu Sina. Jurnal Aksioma Ad-Diniyah, 2(2).

Sujana, I. W. C. (2019). Fungsi Dan Tujuan Pendidikan Indonesia. Adi Widya: Jurnal Pendidikan Dasar, 4(1), 29.

Supriyadi. (2017). Community of Practitioners: Solusi Alternatif Berbagi Pengetahuan antar Pustakawan. Lentera Pustaka: Jurnal Kajian Ilmu Perpustakaan, Informasi Dan Kearsipan, 2(2), 83.

Suyadi, A. B. H. \&. (2019). Relevansi Konsep Akal Bertingkat Ibnu Sina dalam Pendidikan Islam di Era Milenial. Ta'dibuna: Jurnal Pendidikan Islam, 8(2), 222-240.

Syafe'i, T. H. \& M. (2018). Filsafat Perencanaan Dan Implikasinya Dalam Perencanaan Pembelajaran Pendidikan Agama Islam Di Sekolah. Jurnal Lemtera Pendidikan, 21(2), 188-205.

Syahidin. (2019). The Teacher Education In Islamic Views: A Conceptual Analysis To Increase Teacher and Lecturer Professionalism Islamic Religious Education In Indonesia. International Journal of Recent Scientific Research, 8(1960), 2058720592.

Syahidin. (2019). Aplikasi Metode Pendidikan Qurani dalam Pembelajaran Agama Islam di Sekolah. Bandung: UPI Press. 